\title{
The Influence of Social Attitude on Cognitive Competence and Practices in Learning Governance Courses on Family Welfare Education Students
}

\author{
Luh Masdarini ${ }^{1, *}$ Ida Ayu Putu Hemy Ekayani ${ }^{1}$ \\ ${ }^{1}$ Family Welfare Education Study Program, Universitas Pendidikan Ganesha, Singaraja, Indonesia \\ *Corresponding author. Email: masdarini@undiksha.ac.id
}

\begin{abstract}
The aims of this study were 1) to determine the effect of social attitudes on cognitive competence in the culinary arts course for family welfare education students, 2) to determine the effect of social attitudes on practical competence in the culinary arts course to family welfare education students, 3) to determine the interaction of social attitudes. on cognitive competence and practical competence in the culinary arts course for family welfare education students. The method used to collect data is a questionnaire method, knowledge test, and observation with instruments in the form of a closed statement questionnaire to collect data on social attitudes, multiple choice knowledge test to obtain data on cognitive competence in the form of student understanding in the culinary arts course, and an observation rubric. to obtain data on the practical competence of students in the culinary arts course. The results showed that 1) different competencies were not influenced by different social attitudes in the Dishes course, 2) the level of student social attitudes did not affect students' cognitive competence and practice, meaning that students from various levels of social attitudes, both high and medium social attitudes. or low have relatively balanced cognitive and practical competencies in the culinary arts course, 3 ) there is no significant interaction between students' social attitudes towards competence in the culinary arts course. Students who have high, medium and low social attitudes have relatively the same cognitive and practical competencies.
\end{abstract}

Keywords: Cognitive competence, Cuisine, Practical competence, Social attitude.

\section{INTRODUCTION}

The purpose of education is not merely to pay attention to aspects of knowledge, but to form individuals who have good and independent personalities. The purpose of national education is closely related to the potential of students such as knowledge, attitudes, skills, and personality of students. Education teaches individuals about the values and norms that apply in society as a guide in regulating behavior. Over time, the development of technology and information has a major impact on various sectors such as: information, communication, culture, politics, economy, and education. This development is known as the flow of globalization. Each individual must be critical of everything that is received. Through the development of technology and information, many students are carried away by the negative currents of globalization. They tend to behave deviate from the norms that apply in society, such as individualist behavior to anarchic behavior. This opinion is also supported by [1] which states that self-efficacy plays an important role in behavior change efforts that can improve one's performance through education. Selfquality is an important determinant in carrying out tasks and responsibilities successfully.

The same thing was also stated by [2] which stated that the impact that occurred from the times or the impact of globalization could be in the form of positive impacts and negative impacts. One of the positive impacts is that it can make it easier or faster for humans to get information, while the negative impact is that school-age children are treated to inappropriate information, watch soap operas for adults, play games that are less educative. It is rooted in this that the role of education becomes quite vital in forming a good person.

Thus, it can be stated that education aims to humanize humans, as stated in the humanistic theory that the learning process must begin and be aimed at the 
interests of humanizing humans themselves. A humanist figure, Habermas stated that new learning will occur if there is interaction between the individual and his environment. The learning environment in question is the natural environment and the social environment, because the two cannot be separated. In this case, Habermas divides learning into three types, namely: 1) technical learning, 2) practical learning, and 3) emancipatory learning [3]. Meanwhile, Bloom's Theory states that the form of behavior must be formulated in educational goals which are divided into three areas, namely: cognitive, affective, and psychomotor fields. The cognitive field relates to intellectual abilities, the affective domain relates to attitudes, values and appreciation, as well as the psychomotor domain which includes all behavior that uses the nerves and muscles of the body $[4]$.

Learning in the 21 st century is a challenge for both teachers and students. The Delors Report (1996) from the International Commission on Education for the Twenty-first Century proposed four learning visions, hereinafter known as the four pillars of education in the 21 st century, including learning to know, learning to do, learning to be and learning to live together. Among the four pillars, learning to be and learning to live together are closely related to the ability of students to interact in a social environment. Linguistically, social has a meaning related to society. Thus, social attitude is an individual's attitude regarding himself and other people or society, where this attitude is carried out in order to maintain good relations between one person and others so that they can live together side by side well and provide mutual benefits [5].

Reference [6] states that attitude is a state of self in humans that moves to act or act in social activities with certain feelings in response to situation objects or conditions in the surrounding environment. In addition, attitude also provides readiness to respond positively or negatively to objects or situations. Social and crosscultural skills are indispensable in realizing the success of students at school and in the community. Social skills enable a person to interact effectively with others, work effectively in a team that has diverse members, have rational thinking and be flexible about ideas and values.

Different values, and using socio-cultural differences to generate ideas, innovations, and better quality of work [7] Furthermore, it is also stated that personal responsibility, self-regulation, and initiative should also be developed to anticipate the high level of interaction and teamwork in the 21 st century work environment.

The social attitudes developed include appreciation and practice of honest, disciplined, polite, caring behavior (mutual assistance, cooperation, tolerance, peace), responsibility, responsiveness, and proactiveness. These attitudes are expected to be internalized and practiced by students in interacting effectively in accordance with the development of children in the environment, family, school, community and natural environment, nation, state, regional area, and international area. However, in reality social attitudes are still not maximally empowered in learning.

Research conducted[8]. shows that the frequency of attitude assessment carried out by teachers is still very low. Teachers still experience obstacles in conducting attitude assessments, and still have to further improve their understanding of the character of each student. Teachers also still have to consult a lot with the KKG teacher group regarding the implementation of student attitude assessments. Similarly, research[9] it was found that teachers still experience problems in assessing students' social attitudes. The constraints expressed were difficulties in determining competence and indicators of social attitude display, difficulty in compiling assessment rubrics, lack of careful observation, lack of skill in determining technical assessments and difficulties in describing conclusions from assessment data. This shows that indeed not all teachers understand that social attitudes are equally important to be developed in learning, in addition to learning outcomes and various other thinking skills.

Not only at the high school level, social attitudes are still not optimally empowered up to the tertiary level. Research conducted [10] on students of the biology education study program at one university also showed that students' social attitudes were still low. The low social attitude is indicated by a lack of responsibility; lack of respect for colleagues of different ethnicity, religion, race, culture, and gender; and a lack of willingness to cooperate with other ethnic groups. The results of this study are in line with the results of observations that the researcher did the students in taking part in learning where some social attitudes looked deviant such as not participating in the assigned group assignments, not paying attention when the learning process took place, and being late for lectures. As educators are responsible for giving warnings, guidance, advice, or coaching to related students. Although several ways have been done to overcome the deviant social attitudes of students, problems regarding social attitudes still occur. If these conditions are not handled properly, it is feared that problems will occur which are certainly not good for the learning climate. Moving on to these phenomena, researchers are interested in raising these problems in the form of research.

\section{METHOD}

The method used to collect data in this study is a questionnaire method, knowledge test, and observation. Questionnaire method was used to collect data on social attitudes, tests were used to measure cognitive 
competence which included students' understanding of the culinary arts course. Furthermore, the observation method was used to collect data on students' practical competencies related to student performance in the culinary arts course.

Based on the method used, this research instrument includes: a questionnaire in the form of a closed statement to collect data on social attitudes, a multiple choice knowledge test to obtain data on cognitive competence in the form of student understanding in the culinary arts course, and an observation rubric to obtain data on competence. practical (psychomotor) which includes student performance in the culinary arts course. Data collection techniques using online methods via google form. The subjects of this study were students of the 6th semester of the Family Welfare Education Study Program, Department of Industrial Technology, Faculty of Engineering and Vocational Education, Ganesha University of Education, totaling 76 people. The sampling technique was purposive sampling.

Data analysis technique is the method used in processing the data that has been collected in research to test the hypothesis that has been proposed. To be able to achieve this goal, in this study the authors used a twoway analysis of variance with a 2 × 3 factorial design. The questionnaire was distributed to determine social attitude skills student. The score for filling out the questionnaire is arranged based on the highest score to the lowest score. Each class is assigned $27 \%$ of the top ranking classified as a group of students who have high social attitudes and $27 \%$ of the lowest ranking is classified as a group of students who have low social attitudes[11].

The data collected in this study include data on students' social attitudes towards cognitive competence and practice in the Dishes course. The type of instrument used is a multiple-choice test with validity test using the Point Biserial Corelation formula and reliability testing using the KR20 formula. The type of social attitude instrument is a questionnaire with validity test using Product Moment correlation and reliability using Cronbach's Alpha.

The data obtained through the research instrument were analyzed using descriptive and inferential analysis. Descriptive analysis is done by presenting the distribution table, average and standard deviation. The normality test in this study used the Liliefors Test. While the homogeneity test used the Bartlett test at the level of $=0.05$. Hypothesis testing in this study used the analysis of variance (ANOVA) to test the main effects and interactions between $\mathrm{A}$ and $\mathrm{B}$.

\section{RESULTS AND DISCUSSION}

Table 1. Data on Social Attitudes of Experimental Group Students

\begin{tabular}{|l|c|c|}
\hline $\begin{array}{l}\text { Student } \\
\text { Social } \\
\text { Attitude }\end{array}$ & $\begin{array}{c}\text { Absolute } \\
\text { Frequency }\end{array}$ & $\begin{array}{c}\text { Relative } \\
\text { Frequency (\%) }\end{array}$ \\
\hline Tall & 11 & 28,95 \\
\hline Currently & 23 & 60,53 \\
\hline Low & 4 & 10,52 \\
\hline Amount & 38 & 100 \\
\hline
\end{tabular}

Table 2. Data on Social Attitudes of Control Group Students

\begin{tabular}{|l|c|c|}
\hline $\begin{array}{c}\text { Student } \\
\text { Social } \\
\text { Attitude }\end{array}$ & $\begin{array}{c}\text { Absolute } \\
\text { Frequency }\end{array}$ & $\begin{array}{c}\text { Relative } \\
\text { Frequency }(\%)\end{array}$ \\
\hline Tall & 3 & 7,89 \\
\hline Currently & 25 & 65,79 \\
\hline Low & 10 & 26,32 \\
\hline Amount & 38 & 100 \\
\hline
\end{tabular}

\subsection{Student Social Attitude Score Data}

Data on student social attitudes from the questionnaire were then grouped into 3 categories based on the average and standard deviation of the entire sample. From the calculation results, the mean of the two groups is 166.263158 , while the standard deviation of the two groups is 12.571318 . For scores that are more than $166,263158+12.571318$ are categorized as high, for scores less than 166,263158 - 12.571318 are categorized as low. Meanwhile, scores less than $166,263158+12.571318$ and scores more than $166,263158-12,571318$ are categorized as moderate. With these criteria there are 14 students who have high social attitudes, 48 students have moderate social attitudes and 14 students have low social attitudes out of 76 students altogether

Based on the data obtained, for the experimental group there were 11 students with high social attitudes, 23 students with moderate social attitudes, and 4 students with low social attitudes (Table 1). Furthermore, for the control group, the number of students who have high social attitudes, moderate social attitudes and low social attitudes can be seen in the Table 2 .

\subsection{Testing Requirements Analysis}

As for testing the hypothesis using the ANOVA analysis technique of two unequal cell paths, it is necessary to carry out a prerequisite test to fulfill the ANOVA analysis technique of two unequal cell paths, namely: Normality Test, Homogeneity Test which was previously tested for balance first. 


\subsubsection{Balance Test}

The balance test was carried out to see whether the experimental class and the control class were commensurate / equal between the conditions before there was a different treatment. For the balance test, it is taken from the final semester exam scores with odd semesters, namely for the experimental class it has a Mean 5.1052632 and a Variance of 0.9378094 with 38 students, while for the control class with 38 students, the mean is 4.94736842 and the variance is 0.8512091 . The results of the balance test using the $t$ test, obtained $t$ count $=0.769413428$ with $\mathrm{t} 0.05=1.96$. So it can be concluded that the experimental group and the control group are in a balanced state.

\subsubsection{Normality test}

The normality test used in this study is the Lilliefors test, this test is used to fulfill one of the assumptions needed in a two-way analysis of variance with unequal cells, namely to see whether the data obtained from the sample comes from a normally distributed population. Normality test results from each cell are presented in the Table 4.

Taking into account the six hypotheses in the Normality test that Lcount < Ltable, it can be concluded that the data comes from a normally distributed population.

\subsubsection{Homogeneity Test}

Homogeneity test was conducted to show that the population of this research sample was homogeneous or had the same variance. The results of the homogeneity test using the Bartlett method are presented in the Table 4.

From the three analyzes in the homogeneity test above, it can be concluded that the populations of this research sample are homogeneous or have the same variance.

\subsubsection{Hypothesis test}

After the assumptions needed in the analysis of variance are met, then A two-way analysis of variance will be tested with unequal cells. The results of the calculation of the two-way analysis with unequal cells are presented in the Table 5.

Table 3. Results of Normality Test Analysis

\begin{tabular}{|l|l|l|l|}
\hline Source & L count & L table & Decision \\
\hline A1 & 0.0988 & 0.1437 & Normal \\
A2 & 0.0765 & 0.1437 & Normal \\
B1 & 0.1769 & 0.2270 & Normal \\
B2 & 0.0867 & 0.1279 & Normal \\
B3 & 0.1586 & 0.2270 & Normal \\
\hline
\end{tabular}

Table 4. Results of Homogeneity Test Analysis

\begin{tabular}{|c|c|c|c|}
\hline Source & $\begin{array}{l}\text { X2 } \\
\text { count }\end{array}$ & $\begin{array}{c}\mathrm{X} 2 \\
\mathrm{~L} \text { table }\end{array}$ & Decision \\
\hline $\begin{array}{l}\text { A (Student } \\
\text { Competencies) }\end{array}$ & 0.746 & 3.841 & Homogeneous \\
\hline $\begin{array}{l}\text { B (social } \\
\text { attitude) }\end{array}$ & 0.891 & 5.991 & Homogeneous \\
\hline
\end{tabular}

Table 5. Summary of Variance Analysis Results of Two Dissimilar Cell Paths

\begin{tabular}{|l|c|c|c|l|l|l|}
\hline \multicolumn{1}{|c|}{$\begin{array}{c}\text { Source } \\
\text { Variance }\end{array}$} & DK & JK & RK & $\begin{array}{l}\text { F } \\
\text { count }\end{array}$ & FTable & Decision \\
\hline$A$ (Line) & 1 & 0.3195 & 0.3195 & 0.5908 & 3.18 & HoA \\
B (columm) & 2 & 0.3142 & 0.1571 & 0.1434 & 3.13 & accepted \\
AB(Interaction) & 2 & 1.6647 & 0.8323 & 0.7594 & 3.13 & HoB \\
G(Error) & 70 & 76.720 & 1.0960 & & & $\begin{array}{l}\text { accepted } \\
\text { HoAB } \\
\text { accepted }\end{array}$ \\
Total & & & & & & \\
\hline
\end{tabular}

\subsubsection{First Hypothesis}

From the two-way analysis of variance obtained $\mathrm{F}$ count $=0.590>\mathrm{F}$ table $=3.18$ it can be concluded that the null hypothesis is accepted. This states that different competencies are not influenced by different social attitudes in the Dishes course.

\subsubsection{Second Hypothesis}

From the two-way analysis of variance, $\mathrm{F}$ count = $0.143<\mathrm{F}$ table $=3.13$ or it means that the null hypothesis is accepted. The acceptance of HOB can be concluded that the level of student social attitudes has no effect on students' cognitive competence and practice, meaning that students from various levels of social attitudes, both high, medium and low social attitudes, have relatively balanced cognitive and practical competencies in the culinary arts course.

\subsubsection{Third hypothesis}

From Anova two unequal cell paths obtained $\mathrm{F}$ count $=0.760<\mathrm{F}$ table $=3.13$ it is concluded that the null hypothesis is accepted. This means that there is no significant interaction between students' social attitudes towards competence in the culinary arts course. Students who have high, medium and low social attitudes have relatively the same cognitive and practical competencies.

\subsection{Discussions}

From the research that has been done, the results can be explained as follows:

From the two-way analysis of variance, $\mathrm{F}$ arithmetic $=0.590>\mathrm{F}$ table $=3.18$, it can be concluded that the 
null hypothesis is accepted. This states that different competencies are not influenced by different social attitudes in the Dishes course. This is due to the activeness of students in the teaching and learning process which can be clearly demonstrated by students during the teaching and learning process that social attitudes do not play an important role in students' cognitive competence and practice in the culinary arts course. When learning activities take place in class, students are motivated by the problems posed by the teacher, students who have high, medium and low social attitudes all try to be able to master the material and try to solve them both individually and in groups.

There is no significant effect between students who have high, medium and low social attitudes on cognitive competence and practice in the culinary arts course. It can be seen from the results of the two-way ANOVA calculation that $\mathrm{F}$ count $=0.1434$ at $=0.05$ is smaller than $\mathrm{F}$ table $=3.13$ at $=0.05$. It means that students who have high social attitudes, cognitive competence and practice are relatively the same as students who have moderate social attitudes, as well as students who have moderate social attitudes, cognitive competence and practice are the same as students with low social attitudes. Most likely the things that led to the acceptance of Ho in this second hypothesis were due to: 1) factors from individual students, namely the possibility that there was no independence or a mindset that was still innocent or innocent from students, so that in choosing answers to the questionnaire social attitudes students chose answers that had not been able to state. his true attitude. Besides, students' social attitudes may not yet become an absolute demand in their application in the family and society. For example, it appears in managing his emotions when he is with his peers, which is only following along, not because of encouragement from himself. 2). the factor of the relatively short research time which is only approximately one month or only 4 face-to-face meetings in the learning process, so that social attitude possessed by each student is not yet clear according to the character of each student. It seems that the child has not responded positively to the learning activities carried out and has not been able to condition or take the right position according to his personal attitude. Although the learning process has been designed to display students' social attitudes, what appears is just what it is and is difficult to change or engineer because the student learning model is still individual. So that this research will give better results if it takes enough time because it can find out the social attitudes of students more deeply and clearly.

There is no significant interaction between students' social attitudes towards cognitive competence and practice in the culinary arts course. This can be seen from the calculation results, where $\mathrm{F}$ count $=0.760$ at $=$ 0.05 is smaller than $\mathrm{F}$ table $=3.13$ at $=0.05$. This means that students who have high social attitudes, cognitive competence and practice are relatively the same. Likewise for students who have moderate and low social attitudes. This may be influenced by the following factors: (1) The result of student persistence means that student competence is the result of student persistence in learning and does not reflect the student's personal attitude or a reflection of the student's social attitude; (2) The social attitude questionnaire that was tested by the researcher may not be in accordance with the overall level of student development. Besides the other possibility that in the preparation of the social attitude questionnaire grid, it has not been able to measure social attitudes, meaning that it has not met the expected standards even though the preparation has referred to the level of aspects in general that students do in everyday life in the family environment and in the community.

\section{CONCLUSION}

Based on the results of the research and discussion above, it can be concluded as follows: (1) Different competencies are not influenced by different social attitudes in the Dishes course; (2) The level of student social attitudes does not affect students' cognitive competence and practice, meaning that students from various levels of social attitudes, both high, medium and low social attitudes, have relatively balanced cognitive and practical competencies in the culinary arts course; (3) There is no significant interaction between students' social attitudes towards competence in the culinary arts course. Students who have high, medium and low social attitudes have relatively the same cognitive and practical competencies.

\section{REFERENCES}

[1] V. K. Kolil, S. Muthupalani, and K. Achuthan, "Virtual experimental platforms in chemistry laboratory education and its impact on experimental self-efficacy," Int. J. Educ. Technol. High. Educ., vol. 17, no. 1, 2020, doi: 10.1186/s41239-020-00204-3.

[2] N. Nurfirdaus and Risnawati, "Studi Tentang Pembentukan Kebiasaan Dan Perilaku Sosial Siswa (Studi Kasus di SDN 1 Windujanten)," J. Lensa Pendas, vol. 4, no. 1, pp. 36-46, 2019.

[3] A. Budiningsih, Belajar dan Pembelajaran. Jakarta: Rineka Cipta, 2015.

[4] A. Armo, A. Jazuli, and T. Tanireja, "Hubungan Sikap Sosial Dan Kecerdasan Emosional Terhadap Prestasi Belajar Siswa Sekolah Dasar Di Wilayah Kecamatan Gumelar Di Tinjau Dari Gender," Din. J. Ilm. Pendidik. Dasar, vol. 11, no. 1, p. 58, 2019, doi: 10.30595/dinamika.v11i1.5979. 
[5] A. Wiguna, "Upaya Mengembangkan Sikap Spiritual dan Sosial Peserta Didik Berbasis Psikologi Positif di Sekolah,” Al-ASASIYYA J. Basic Educ., vol. 1, no. 2, pp. 47-61, 2017.

[6] I. W. Widiana, I. G. Nurjaya, G. W. Bayu, and P. W. Noviana, "Analisis Rekonstruksi Sikap Sosial Siswa Tuna Rungu," Int. J. Elem. Educ., vol. 3, no. 4, p. 518, 2019, doi: 10.23887/ijee.v3i4.22559.

[7] M. S. Bialangi, "Development of Social Attitude in Biology Learning: Review of Cooperative Learning Potential."

[8] S. Fitriana, "Peranan Permainan Edukatif Dalam Menstimulasi Perkembangan Kognitif Anak," Al Fitrah J. Early Child. Islam. Educ., vol. 1, no. 2, p. 131, 2018, doi: 10.29300/alfitrah.v1i2.1339.

[9] M. Marlina, Asrori, "Penerapan Penilaian Sikap Sosial dalam Pembelajaran Tematik di Kelas V Sekolah Dasar Negeri 39 Marlina, Asrori, Martono," J. Pendidik., vol. 11, no. 3, pp. 1-16, 2019.

[10] Y. Bustami, A. D. Corebima, E. Suarsini, and Ibrohim, "The social attitude empowerment of biology students: Implementation JiRQA learning strategy in different ethnics," Int. J. Instr., vol. 10, no. 3, pp. 15-30, 2017, doi: 10.12973/iji.2017.1032a.

[11] Sugiyono, Metode Penelitian Pendidikan (Kuantitatif, Kualitatif, R \& D, dan Penelitian Pendidikan). Bandung: Alfabeta, 2015. 